кuLTura- мeDia- TeoLogia

ISSN 2081-8971

$2017 \mathrm{nr} 30$, s. 151-160.

\title{
Millenialsi i ich „tele-wizje”. Geneza i konstrukcja programu badawczego
}

\section{Millenials and their "tele-visions". Genesis and construction of a research programme.}

\begin{abstract}
STRESZCZENIE:
ARTYKUŁ STANOWI PREZENTACJE PROJEKTU BADANIA POD NAZWĄ ,TELEWIZJA TRADYCYJNA, ON-LINE I SPOŁECZNOŚCIOWA JAKO NARZĘDZIE EDUKOWANIA POKOLENIA Y”. PRZEDSTAWIONO PUNKT WYJŚCIA DO BADAŃ NA TEMAT SZEROKO ROZUMIANEGO KONSUMOWANIA TELEWIZJI WŚRÓD PRZEDSTAWICIELI POKOLENIA TZW. „MILLENIALSÓW”. CZĘ̧́́ TEORETYCZNA DOTYCZY PROBLEMATYKI WSPÓŁCZESNEGO KOMUNIKOWANIA SPOŁECZNEGO W NAWIĄZANIU DO EDUKACJI MEDIALNEJ. DRUGA CZĘŚĆ ZAWIERA PREZENTACJĘ NARZĘDZIA BADAWCZEGO, TJ. ANKIETY OPRACOWANEJ W RAMACH PROJEKTU, KTÓRY DOTYCZYŁ RÓŻNYCH FORM ODBIORU TELEWIZJI PRZEZ

PRZEDSTAWICIELI POKOLENIA Y. AUTOR OPISUJE RÓWNIEŻ PRZEBIEG TEGO BADANIA WŚRÓD STUDENTÓW DZIENNIKARSTWA UNIWERSYTETU KARDYNAEA STEFANA

WYSZYŃSKIEGO I UNIWERSYTETU WARSZAWSKIEGO.

NAJWAŻNIEJSZE WYNIKI ANKIETY POZWALAJA SFORMUŁOWAĆ KOLEJNE PYTANIA BADAWCZE ZWIĄZANE Z POTRZEBAMI, MOTYWACJA, OCZEKIWANIAMI I NAWYKAMI „MILLENIALSÓW”.
\end{abstract}

\section{SŁOWA KLUCZOWE:}

TELEWIZJA, POKOLENIE Y, MILLENIALSI, EDUKACJA MEDIALNA, INTERNET

\begin{abstract}
:
THE ARTICLE FORMS A PRESENTATION OF A PREPARATION TO CONDUCT A RESEARCH PROJECT, TITLED “TRADITIONAL, On-line And Social Television As A Tool For GENERATION Y EDUCATION”. AN ENTRY POINT TO RESEARCH ON BROADLY-UNDERSTOOD TV CONSUMPTION AMONG MILLENIALS HAS BEEN SHOWN. THE THEORETICAL PART COVERS CONTEMPORARY MASS COMMUNICATION IN RELATION TO MEDIA EDUCATION. PART TWO IS A PRESENTATION OF A RESEARCH TOOL, I.E. A SURVEY CONSTRUCTED DURING THE COURSE OF A PROJECT ON TV RECEPTION FORMS BY THE GENERATION Y. IT ALSO SHOWS ITS PROGRESSION AMONG THE JOURNALISM STUDENTS OF CARDINAL WyszyŃSKI UnIVERSITY AND WARSAW UNIVERSITY. THE KEY SURVEY RESULTS JUSTIFY CONSTRUCTION OF FOLLOW-UP QUESTIONS RELATED WITH NEEDS, MOTIVATION, EXPECTATIONS AND HABITS OF MilLENIALS.
\end{abstract}

\section{KEYWORDS:}

Television, Generation Y, Millenials, Media EduCATION, The INTERNET 
$\mathrm{P}$ roces tworzenia i wykorzystywania kanałów dystrybucji, powstających na bazie technologii mobilnych dla wyprodukowanych przez media treści, w znacznym stopniu przyczynił się do zmiany oblicza współczesnych mediów. Internet stał się kluczową platformą w zakresie komunikowania masowego, a dotychczasowe, nazywane też tradycyjnymi, sposoby nadawania, nie są dla nowych pokoleń odbiorców kanałami atrakcyjnymi. Dzieje się tak ze względu na ograniczenia ilościowe oferty, zasięg, a także niewielką, w stosunku do mediów internetowych, możliwość wpływu na kształt i treść wybieranych przekazów.

W celu przeprowadzenia wstępnej weryfikacji tez, związanych z konsumpcją mediów audiowizualnych wśród studentów kierunków dziennikarskich dwóch warszawskich uczelni - Uniwersytetu Warszawskiego i Uniwersytetu Kardynała Stefana Wyszyńskiego, opracowane zostały pilotażowe badania pt. „Telewizja tradycyjna, on-line i społecznościowa jako narzędzie edukowania pokolenia Y”. Badaniem zostali objęci tylko ci studenci, którzy przynależą do tzw. pokolenia $\mathrm{Y}^{1}$. Cele poznawcze badania, do przeprowadzenia którego zostało stworzone narzędzie w formie ankiety on-line, obejmowały m.in.: badanie sposobów konsumowania telewizji przez przedstawicieli pokolenia Y, wyjaśnienie czynników wpływających na sposób konsumowania telewizji, preferowanych audycji telewizyjnych, poszukiwanych treści czy źródeł wiedzy na temat audycji telewizyjnych. Zakładano, że projektowane badanie powinno przynieść odpowiedzi na stawiane pytania badawcze, m.in jak i w jakim stopniu przedstawiciele pokolenie Y konsumują telewizję tradycyjną, a także co wpływa na wzrost lub zmniejszenie zainteresowania telewizją, jakie nawyki/zwyczaje konsumowania różnych gatunków telewizyjnych możemy zaobserwować?

Jednak zarówno w trakcie rozmów przed wykonaniem badania, jak i podczas spotkań briefingowych zespołu badawczego ${ }^{2}$ oraz po wykonaniu samego badania, pojawiło się wiele dodatkowych pytań. Większość z nich przedstawiono w poniższym opracowaniu. Dotyczyły one zarówno edukacji medialnej, pokolenia Y, edukowania konsumentów, mediów społecznościowych, jak i postaw społecznych. Projekt powyższego badania zakładał, że wyniki, przynajmniej w części dotyczącej telewizji jako narzędzia edukowania, przyniosą odpowiedzi stanowiące punkt wyjścia do dalszych badań.

\section{Geneza badań odbioru telewizji wśród przedstawicieli pokolenia Y}

Pomysł na przeprowadzenie ankiety zrodził się w trakcie zajęć prowadzonych przez pracowników Instytutu Edukacji Medialnej i Dziennikarstwa UKSW. Podczas ćwiczeń z przedmiotów obejmujących swym programem zagadnienia związane z public relations, marketingiem medialnym czy promocją, zauważono istotne, charakterystyczne dla po-

\footnotetext{
${ }^{1}$ W literaturze naukowej brak jednoznacznych granic wiekowych, oznaczających przynależność do pokolenia Y (również: pokolenie Millenium, millenialsi, generacja Why). Umownie określa się tak pokolenie osób urodzonych w latach 1980-2000.

${ }^{2}$ Zespół tworzyli przedstawiciele Instytutu Edukacji Medialnej i Dziennikarstwa UKSW oraz Laboratorium Badań Medioznawczych UW. Prace nad przygotowaniem badania rozpoczęto w marcu 2017.
} 
kolenia Y, postawy w podejściu do konsumowania telewizji, zwłaszcza w jej tradycyjnej, tzw. linearnej formie ${ }^{3}$. Odejście od znanej od dziesięcioleci formuły oglądania telewizji stało się faktem, zmiany te były widoczne również w postawach studentów kierunków dziennikarskich. Uwidaczniały się one zwłaszcza w trakcie dyskusji, ale także w czasie grupowych i indywidualnych zadań, przedmiotem których były przekazy telewizyjne. W zgodnej opinii prowadzących zajęcia zjawisko to było znaczące i niosło ze sobą potencjał badawczy. Bardzo duże znaczenie przy podejmowaniu decyzji o zbadaniu postaw studentów, miało podejście pracowników Instytutu Edukacji Medialnej i Dziennikarstwa UKSW do jak najlepszego opracowania programów nauczania.

Dobrze obrazuje to przykład z przedmiotu „Zintegrowany marketing medialny”, realizowanego na I roku studiów na kierunku „Dziennikarstwo i komunikacja społeczna” UKSW, w roku akademickim 2016/17. W trakcie zajęć omawiano aktualne programy rozrywkowe, emitowane w ogólnodostępnych kanałach telewizyjnych. W kolejności były to: „Agent Gwiazdy” (TVN), „Kuba Wojewódzki” (TVN) oraz festiwal „Eurowizja” (TVP). W ćwiczeniach uczestniczyły cztery grupy studentów, łącznie ok. 110 osób. Większość z nich, pytana o program, jego zasady, uczestników, historię czy zwycięzców, potrafiła wskazać istotne wątki. Jednocześnie jedynie niespełna 10 osób spośród wszystkich, którym stawiano pytanie, przyznała się do oglądania ww. programów w telewizji tradycyjnej. Skąd zatem pozostałe osoby (ok. 100) miały wiedzę na temat omawianych programów? Informacje czerpały z transmisji bądź relacji dostępnych w Internecie, mediach społecznościowych lub VOD V $^{4}$ Uznano, że przytoczony powyżej przypadek mógł stanowić punkt wyjścia dla badań jakościowych i ilościowych.

Podjęta inicjatywa związana jest także z edukacją medialną ${ }^{5}$, a więc również z zadaniami, jakie stawia ona przed prowadzącymi zajęcia dydaktyczne. Według Jana Jaroszyńskiego, edukacja medialna polega „(...) na kształceniu w dziedzinie narzędzi komunikowania społecznego w celu zrozumienia ich natury, oddziaływania oraz efektywnego wykorzystania. Dzięki takiemu podejściu odbiorcy są wszechstronnie przygotowani do posługiwania się mediami, przybierając właściwe postawy" ${ }^{6}$.Zatem, właściwe poznanie świata odbiorców mediów, w tym wypadku telewizji, wydaje się być fundamentalne $\mathrm{w}$ procesie tworzenia programu zajęć z wybranych przedmiotów (ćwiczeń) prowadzonych w toku studiów dziennikarskich.

W tym miejscu warto na chwilę zatrzymać się przy ogólnej charakterystyce „millenialsów”, nie tylko jako studentów. Jest to pierwsze, liczące już ok. 9 milionów pokolenie, które dorastało w warunkach gospodarki rynkowej. Oceniane jako wykształcone,

\footnotetext{
${ }^{3}$ Linearny sposób nadawania programów ujęty jest w tzw. ramówkę, w której stacja telewizyjna określa kolejność nadawanych programów i godziny emisji.

${ }^{4}$ Ang. Video On Demand, video na żądanie - usługa która umożliwia oglądanie filmu lub programu (także nadawanego na żywo) w czasie wybranym przez odbiorcę (późniejszym od emisji).

${ }^{5}$ „Edukację medialną możemy definiować jako wychowanie do korzystania z mediów”, cyt. za: P. Drzewiecki, Edukacja medialna a nauczanie religii w szkole, Warszawa 2013, s. 27.

${ }^{6}$ J. Jaroszyński, Sport jako wyzwanie dla edukacji medialnej, w: M. Jarosz, P. Drzewiecki, P. Płatek (red.), Sport w mediach, Warszawa 2013, s. 257-258.
} 
świadome i pewne siebie, ale także egoistyczne, roszczeniowe i nielojalne - zwłaszcza wobec pracodawców, gdyż w przeciwieństwie do przedstawicieli pokolenia $\mathrm{X}^{7}$, nie boją się zmian miejsca pracy i mają wobec niej określone wymagania, czasem trudne do zaakceptowania przez firmy przyzwyczajone do dyktowania warunków zatrudnienia. W odróżnieniu od wcześniejszych pokoleń, dla pokolenia Y ważne jest zachowanie zasady work-life-balance ${ }^{8}$. Zatem nic dziwnego, że pomiędzy przedstawicielami pokoleń, zwłaszcza w relacji zwierzchnik-podwładny, dochodzi do nieporozumień, których źródłem często bywa właśnie konflikt wartości. Sylwia Radzięta z firmy Sedlak\&Sedlak, zajmującej się doradztwem personalnym i analizami rynku pracy, w ten sposób ujmuje charakterystyczne dla „millenialsów” podejście do rynku pracy: „Ludzie tego pokolenia nie mieli do czynienia z masowymi zwolnieniami, nie wiedzą co to stan wojenny, nigdy nie stali w kilometrowych kolejkach do sklepów, w których de facto nic nie można było nabyć. Samochód, komórka, laptop to dobra powszechnie dostępne. Wszelkie te uwarunkowania doprowadziły do tego, że ludzie młodzi nastawieni są roszczeniowo do świata, wydają się być mało zapobiegliwi i niecierpliwi. Pokolenie Y cechuje się zupełnie innymi wartościami, niż ludzie starsi urodzeni przed rokiem 1960"9.

Decyzje zakupowe podejmowane przez typowego przedstawiciela pokolenia Y są zgoła odmienne od tych, na których opierały swoje postępowanie poprzednie pokolenia. „Z punktu widzenia marek, najważniejszym wyróżnikiem tego pokolenia jest brak chęci posiadania. Millenialsi nie odczuwają potrzeby kupna mieszkania, czy samochodu. Zamiast tego preferują wynajem. Korzystają z Ubera lub przesiadają się na wynajęty rower. (...) Rodzi to oczywiste wyzwanie dla producentów wszelkiego rodzaju dóbr osobistych i usług - jak bowiem przekonać millenialsa, że warto kupić oferowany przez nich produkt lub usługę?” - czytamy w opracowaniu Kazimierza Stańczaka ${ }^{10}$ dla magazynu „Forbes”" . Obserwując kampanie znanych marek z sektora finansowego, można zauważyć trend, który zmienia dotychczas stosowaną taktykę. Przyjmując, że grupa docelowa nie jest zainteresowana braniem kredytów na cele długoterminowe (budowa domu, zakup samochodu), które dotąd były wiodącymi produktami w ofercie banków, propozycje kieruje się biorąc pod uwagę zainteresowania potencjalnych klientów. W przypadku „millenialsów” mogą to być na przykład podróże.

\footnotetext{
${ }^{7}$ Pokolenie osób urodzonych w drugiej połowie XX wieku, jednak definitywne granice nie zostały ustalone. W opracowaniach naukowych najczęściej wymienia się lata 1965-1980.

${ }^{8}$ Koncepcja równowagi pomiędzy życiem zawodowym a prywatnym, powstała w latach 80 . XX wieku w USA. Za: W. Leoński, Work - Life Balance jako praktyka koncepcji społecznej odpowiedzialności biznesu, data publ. 23.07.2015, http://apcz.umk.pl/czasopisma/index.php/AUNC_ZARZ/article/viewFile/AUNC_ZARZ.2015.010/7152 (dostęp: 19.11.2017).

${ }^{9}$ S. Radzięta, Czego spodziewać się po pokoleniu Y?, data publ. 22.09.2014, https://rynekpracy.pl/artykul.php/typ.1/kategoria_glowna.324/wpis.826, (dostęp: 09.09.2017).

${ }^{10}$ Kazimierz Stańczak - Wydział Ekonomii University of Rochester w USA, były prezes zarządu Polbank EFG i wiceprezes zarządu banku Raiffeisen Polbank.

${ }^{11}$ K. Stańczak, Jak sprzedawać tym, którzy nie mają potrzeby posiadania?, data publ. 18.07.2016, https://www.forbes.pl/opinie/millenialsi-pokolenie-y/lfbx6sg, (dostęp: 07.09.2017).
} 


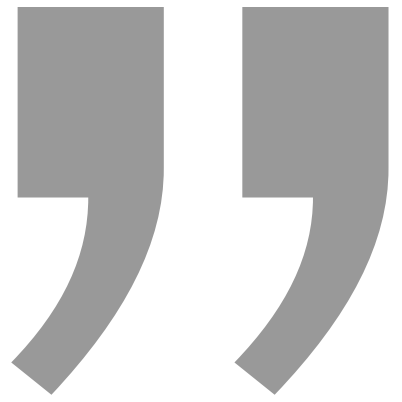

Obserwując kampanie znanych marek z sektora finansowego, można zauważyć trend, który zmienia dotychczas stosowaną taktykę. Przyjmując, że grupa docelowa nie jest zainteresowana braniem kredytów na cele długoterminowe (budowa domu, zakup samochodu), które dotąd były wiodącymi
produktami w ofercie bankiów, propozycje
kieruje się biorąc pod uwagę zainteresowania
potencjalnych klientów. W przypadku
„millenialsów" moğą to być na przykłład podróże.

Pewnemu przewartościowaniu ulega także tradycja marki. Do niedawna potężna broń podczas określania strategii komunikacji, dziś bywa traktowana drugoplanowo, bądź w niektórych wypadkach zupełnie pomijana. Trafnie zauważa to ponownie Kazimierz Stańczak, pisząc: „Na przykład Apple to nie producent nowoczesnych telefonów, ale symbol przynależności społecznej. Noszenie ubrań Adidasa czy Nike’a to nie wygoda i komfort, ale demonstracja stylu życia. Te marki doskonale zdają sobie sprawę, jak ważna jest otoczka wokół brandu. Są przykładami jak budować narrację marki i jak dzięki niej przyciągać młodych klientów" ${ }^{12}$. Receptą na sukces marki w skutecznym dotarciu do pokolenia Y jest także „przeprogramowanie” oferty tradycyjnej na cyfrową. Dzieje się tak dlatego, że relacje z marką opierają się często na kontaktach za pomocą mediów społecznościowych (Facebook) a także na recenzjach, które można znaleźć w Internecie.

\section{Edukacja medialna „millenialsów” i ich następców. Pytania i wnioski do dalszych badań}

$\mathrm{W}$ tym miejscu docieramy do problemu dotyczącego szeroko rozumianej edukacji medialnej. Spotykamy się z nim już wcześniej, bo na etapie definiowania jej roli w procesie kształcenia poszczególnych grup wiekowych. Dzieje się tak w momencie, gdy chcemy zestawić ze sobą możliwości, jakie daje nam media literacy ${ }^{13} \mathrm{z}$ faktycznym zainteresowaniem danym medium (w tym wypadku telewizją), wśród przedstawicieli grupy docelowej. Piotr Drzewiecki, medioznawca i wieloletni propagator edukacji medialnej, we

\footnotetext{
${ }^{12}$ Tamże.

${ }^{13}$ „Media literacy możemy określić jako zdolność do kompetentnej komunikacji we wszystkich formach przekazu, drukowanych i elektronicznych, przejawiającą się w świadomym korzystaniu, rozumieniu, analizie i krytycznej ocenie przekazów słownych, wizualnych i dźwiękowych”. P. Drzewiecki $M E D I A$ AKTYWNI. Dlaczego i jak uczyć edukacji medialnej?, Otwock-Warszawa 2010, s. 13.
} 
wstępie do podręcznika „MEDIA AKTYWNI. Dlaczego i jak uczyć edukacji medialnej?” 14 stwierdza: „Podstawą edukacji medialnej jest mądre planowanie wolnego czasu, by media nie zawłaszczyły go w całości" ${ }^{15}$. Obserwując postępowanie, nawyki i upodobania przedstawicieli pokolenia Y, można jednak zadać pytanie, czy w wypadku tej grupy należy obawiać się o zawłaszczenie czasu przez media? A jeśli tak, to przez jakie media?

$\mathrm{Z}$ pewnością ze względu na szybko zmieniającą się rzeczywistość, zwłaszcza w obszarze współczesnych mediów, na powyższe pytania nie ma łatwych odpowiedzi. Częściowo zdaje się to potwierdzać opublikowany w 2012 roku raport „Cyfrowa przyszłość. Edukacja medialna i informacyjna w Polsce. Raport otwarcia”, który był pierwszą w Polsce próbą kompleksowego opisania stanu wiedzy o kompetencjach medialnych Polaków oraz wizjach rozwoju tych kompetencji. W raporcie znajdziemy opis najważniejszych zagrożeń, wyzwań i obszarów działań związanych z edukacją medialną i informacyjną w Polsce. Autorzy piszą o „(..) konieczności przygotowania i wdrożenia całościowego i komplementarnego programu edukacji medialnej i informacyjnej w naszym kraju" ${ }^{16}$. Jednak, z drugiej strony, są świadomi problemów, związanych zwłaszcza z bardzo szybką dezaktualizacją opracowanych materiałów. We wstępie do raportu Jarosław Lipszyc stwierdza: „Świat komunikacji zapośredniczonej przez media zmienia się w tempie uniemożliwiającym zbudowanie w sferze edukacji medialnej kompletnego zasobu dydaktycznego - nasze potrzeby informacyjne zmieniają się tak szybko, że jakikolwiek sztywny i zamknięty system po prostu nie będzie w stanie odpowiednio szybko na te zmiany reagować. Zmienia się również nasz stan wiedzy na temat kompetencji medialnych polskich obywateli. W miarę, jak „badawcze białe plamy” będą wypełniane treścią, niezbędne będzie wprowadzanie do naszych planów zmian i korekt”"17.

W 2017 roku magazyn „Press” przeprowadził badanie pod nazwą „Kto nas zastąpi?" ${ }^{18}$. Kierowane było do studentów kierunków dziennikarskich z dziewięciu uczelni wyższych w całym kraju, dedykowaną ankietę wypełniło 191 studentów. Wśród wyników, które wydają się być interesujące $w$ dalszych rozważaniach na temat roli edukacji medialnej w kontekście zmian zachodzących w upodobaniach pokolenia Y, na szczególną uwagę zasługują te dane, które traktują o aktualnych trendach w korzystaniu z mediów. Wśród ankietowanych studentów:

- 46 proc. nie ogląda telewizji

- 33,8 proc. nie czyta prasy

\footnotetext{
${ }^{14}$ Podręcznik przygotowano w ramach projektu badań statutowych „Metody aktywizujące w edukacji medialnej”, realizowanego w 2009 r., na Uniwersytecie Kardynała Stefana Wyszyńskiego w Warszawie.

${ }^{15}$ Tamże, s. 7.

${ }^{16}$ Raport: Cyfrowa przyszłość. Edukacja medialna i informacyjna w Polsce, data publ. 08.03.2012, http://nck.pl/badania/318622-raport-cyfrowa-przyszlosc-edukacja-medialna-i-informacyjna-w-polsce/ (dostęp: 04.09.2017).

${ }^{17}$ J. Lipszyc, Cyfrowa przyszłość. Edukacja medialna i informacyjna w Polsce, Warszawa 2012, s. 6.

${ }^{18}$ Raport „Press”: czego oczekują studenci dziennikarstwa, data publ. 05.07.2017, http://www.press.pl/tresc/49112,raport-_press__-czego-oczekuja-studenci-dziennikarstwa (dostęp: 07.09.2017).
} 
- 15,1 proc. nie słucha radia

- 100 proc. korzysta z internetu

Przykłady z zajęć dydaktycznych, podane na początku niniejszego artykułu, wskazują na dość duży dystans do tradycyjnie pojmowanej telewizji wśród obecnych studentów. Jak zatem „edukować medialnie” osoby, które, przynajmniej według obserwacji, są danym medium zainteresowane $\mathrm{w}$ niewielkim stopniu? Piotr Drzewiecki uważa że: „Edukacja medialna jest nie tyle wiedzą o mediach, co sztuką mądrego korzystania z mediów, traktowania ich jako pomocy służących do poznawania prawdy o świecie" ${ }^{19}$. O ile w przypadku dzieci czy osób starszych istnieje realna potrzeba, ale także szansa, na wdrożenie programów, które przyniosą efekty w postaci pomocy odnalezienia się w świecie mediów, o tyle dzisiejsi „millenialsi”, to już nie tylko osoby dojrzałe, ale przede wszystkim wzrastające w otoczeniu mediów, zwłaszcza mediów społecznościowych, które są ich „naturalnym środowiskiem”. Może w takim wypadku powinniśmy z edukacji medialnej wyłączyć tę grupę? A może zmodyfikować wcześniejszy program nauczania i wykreślić z niego te media, którymi dana grupa nie jest zainteresowana? Tylko czy w takim wypadku w dalszym ciągu możemy posługiwać się terminem „edukacja medialna"?

\section{Prezentacja narzędzia badawczego}

Pragnąc znaleźć odpowiedzi na powyższe, ale również wiele innych pytań, które nasuwały się podczas analizowania zagadnienia, zespół badawczy stworzony na UKSW w Warszawie nawiązał współpracę z Laboratorium Badań Medioznawczych Uniwersytetu Warszawskiego, gdzie powstał projekt badania pod nazwą „Telewizja tradycyjna, on-line i społecznościowa jako narzędzie edukowania pokolenia Y”.Podczas opracowania ramowej konceptualizacji badania wyłoniono następujące cele poznawcze, które zakładały:

- zbadanie sposobów konsumowania telewizji przez przedstawicieli pokolenia Y,

- wyjaśnienie czynników wpływających na sposób konsumowania telewizji przez pokolenie Y,

- wskazanie audycji telewizyjnych (gatunki i nazwy własne) preferowanych przez przedstawicieli pokolenia Y,

- wskazanie, jakiego typu treści poszukują przedstawiciele pokolenia Y w poszczególnych gatunkach telewizyjnych,

- ustalenie, skąd pokolenie Y czerpie wiedzę na temat audycji telewizyjnych - ich tematyki, godzin i dni emisji.

Wiedzę na temat przedstawionego problemu badawczego miały dać odpowiedzi na postawione pytania badawcze:

${ }^{19}$ P. Drzewiecki, MEDIA AKTYWNI. Dlaczego i jak uczyć edukacji medialnej?, Otwock-Warszawa 2010, s. 6. 
- czy, a jeśli tak, to jak i w jakim stopniu przedstawiciele pokolenie Y konsumują telewizję tradycyjną?

- jakie czynniki wpływają na wzrost lub zmniejszenie zainteresowania pokolenia Y telewizją tradycyjną (linearną) oraz nielinearną?

- czy i jeżeli tak, to jakie nawyki/zwyczaje konsumowania różnych gatunków telewizyjnych można zaobserwować wśród przedstawicieli pokolenia Y?

Wnioskując z obserwacji, rozmów i ćwiczeń, przeprowadzonych w trakcie zajęć dydaktycznych, postawiono siedem hipotez, których potwierdzenie lub zaprzeczenia oczekiwano w wyniku projektowanej ankiety.

Hipotezy:

1. Gatunek audycji telewizyjnych emitowanych w tradycyjnej telewizji wpływa na poziom oglądalności wśród osób należących do pokolenia Y.

2. Pokolenie Y chętniej korzysta z telewizji nielinearnej niż tradycyjnej.

3. Pokolenie Y nie poszukuje w telewizji tradycyjnej audycji edukacyjnych.

4. Zainteresowanie pokolenia $Y$ jest skoncentrowane na konkretnych audycjach telewizyjnych.

5. Osoby z pokolenia $Y w$ telewizji tradycyjnej częściej oglądają audycje o charakterze rozrywkowym i sportowym niż informacyjnym.

6. Telewizja VOD oraz materiały o charakterze self-publishing wpływają na zmniejszenie zainteresowania pokolenia Y tradycyjną telewizją.

7. Internet jest źródłem wiedzy na temat audycji telewizji tradycyjnej dla osób należących do pokolenia $Y$.

Celem projektu badawczego było określenie sposobów konsumowania telewizji przez przedstawicieli tzw. pokolenia $\mathrm{Y}$ - w tym przypadku studentów studiów dziennikarskich. Założeniem było uzyskanie odpowiedzi na pytania dotyczące czynników wpływających na sposób konsumowania telewizji przez przedstawicieli pokolenia Y oraz poznanie programów, które preferują ${ }^{20}$.

Badanie obejmowało studentów kierunku dziennikarstwo: pierwszego roku studiów licencjackich oraz pierwszego roku studiów magisterskich na Uniwersytecie Kardynała Stefana Wyszyńskiego oraz Uniwersytecie Warszawskim. W celu zapewnienia jak najwyższej frekwencji podczas badania, przeprowadzono je podczas zajęć obowiązkowych. Łącznie kwestionariusz skutecznie i kompletnie wypełniły 363 osoby $^{21}$. Pomiar został przeprowadzony w okresie 22 maja - 1 czerwca $2017 \mathrm{r}$.

W badaniu posłużono się metodą ankiety CAWI (Computer Assisted Web Interviews) realizowaną w modelu audytoryjnym. Przedstawiciele zespołu badawczego stawili się w salach wykładowych na początku zajęć, informowali krótko o charakterze ba-

\footnotetext{
${ }^{20}$ Na podstawie materiałów Laboratorium Badań Medioznawczych Uniwersytetu Warszawskiego

${ }^{21}$ Odpowiednio: Uniwersytet Warszawski - 228 osób, Uniwersytet Kardynała Stefana Wyszyńskiego - 135 osób.
} 
dania, następnie podawali adres strony internetowej, na której znajdował się kwestionariusz. Respondenci wypełniali ankietę za pomocą urządzeń elektronicznych z dostępem do internetu (znaczna większość - na własnych smartfonach, laptopach, tabletach lub w kilku przypadkach - na komputerach stacjonarnych dostępnych w salach zajęciowych).

Kwestionariusz badawczy został wypracowany w toku spotkań i konsultacji zespołu prowadzącego projekt ze strony Uniwersytetu Kardynała Stefana Wyszyńskiego z zespołem wspierającym z Laboratorium Badań Medioznawczych Uniwersytetu Warszawskiego. Po analizie celów projektu badawczego, charakterystyki respondentów, ograniczeń czasowych i możliwości technologicznych oprogramowania wspierającego zbieranie danych wypracowano kwestionariusz, obejmujący 26 pytań (zamkniętych i otwartych, jedno-i wielokrotnego wyboru). Pytania dotyczyły kolejno:

- korzystania z poszczególnych typów telewizji (tradycyjnej, internetowej, VOD) i preferencji w tym zakresie,

- częstotliwości korzystania z poszczególnych typów telewizji,

- oglądanych stacji telewizyjnych,

- celów i motywacji w konsumowaniu poszczególnych rodzajów treści,

- oglądanych audycji telewizyjnych i motywacji, jakie temu przyświecają,

- źródła wiedzy o poszczególnych audycjach telewizyjnych,

- preferencji w wyborze określonego typu telewizji w poszukiwaniu określonego rodzaju treści,

- „typowego” tygodnia telewizyjnego, uwzględniającego wskazanie zazwyczaj oglądanych audycji i stacji w przedziałach godzinowych poszczególnych dni.

Pytania merytoryczne zostały uzupełnione pytaniami metryczkowymi (wiek, płeć, macierzysta uczelnia, rok studiów, kierunek studiów, ukończony kierunek studiów pierwszego stopnia).

\section{Zakończenie}

Wyniki badania poddawane są obecnie analizie, w efekcie której spodziewane jest uzyskanie odpowiedzi na postawione pytania badawcze. Interesujące powinno być także potwierdzenie lub zaprzeczenie przedstawionych hipotez, jak również określenie, czy jakieś pytania należałoby pogłębić lub z których zrezygnować.

Ponadto, wyniki badania mogą posłużyć jako punkt wyjścia do kolejnych badań medioznawczych. W fazie koncepcyjnej jest przygotowanie badań jakościowych (wywiady grupowe). Następnym polem eksploracji mogłoby być porównanie wyników otrzymanych w badaniu studentów dziennikarstwa (obszar nauk społecznych) ze studentami innych kierunków z obszaru nauk ścisłych, technicznych czy przyrodniczych. Projektowane działania dają nadzieję na pogłębienie wiedzy o potrzebach, motywacji, oczekiwaniach i nawykach „millenialsów” wobec różnych typów programów telewizyjnych i różnych sposobów ich emitowania. 


\section{BIBLIOGRAFIA}

Drzewiecki P., MEDIA AKTYWNI. Dlaczego i jak uczyć edukacji medialnej?, Otwock - Warszawa 2010.

Drzewiecki P., Edukacja medialna a nauczanie religii w szkole, Warszawa 2013. Jarosz M., Drzewiecki P., Płatek P. (red.), Sport w mediach, Warszawa 2013.

Leoński W., Work - Life Balance jako praktyka koncepcji społecznej odpowiedzialności biznesu, http://apcz.umk.pl/czasopisma/index.php/AUNC_ZARZ/article/viewFile/AUNC_ZARZ.2015.010/7152, publ. 23.07.2015.

Lipszyc J., Cyfrowa przyszłość. Edukacja medialna i informacyjna w Polsce, Warszawa 2012.

Radzięta S., Czego spodziewać się po pokoleniu Y?, Rynekpracy.pl https://rynekpracy.pl/artykul.php/typ.1/kategoria_glowna.324/wpis.826, publ. 22.09.2014.

Raport: Cyfrowa przyszłość. Edukacja medialna i informacyjna w Polsce, Narodowe Centrum Kultury http://nck.pl/badania/318622-raport-cyfrowa-przyszlosc-edukacja-medialna-i-informacyjna-w-polsce/, publ. 08.03.2012.

Raport „Press”: czego oczekują studenci dziennikarstwa, Press http://www.press.pl/tresc/49112,raport-_press__-czego-oczekuja-studenci-dziennikarstwa publ. 05.07.2017.

Stańczak K., Jak sprzedawać tym, którzy nie mają potrzeby posiadania?, Forbes https://www.forbes.pl/opinie/millenialsi-pokolenie-y/lfbx6sg, publ. 18.07.2016.

Edukacja medialna, http://edukacja-medialna.wyklady.org.

\section{OAUTORZE:}

mgr Tomasz Knecht - asystent w Instytucie Edukacji Medialnej i Dziennikarstwa, Wydział Teologiczny UKSWw Warszawie, KONTAKT: t.knecht@uksw.edu.pl

Absolwent Wydziału Dziennikarstwa i Nauk Politycznych UW i studium Warsaw Journalism Center. Doktorant na Wydziale Nauk Historycznych i Społecznych UKSW. Wieloletni pracownik $w$ działach marketingu mediów i wydawnictw, m.in. G+J Polska (National Geographic), Murator (Super Express), Bauer (Motor), PPWK SA. Pola zainteresowań badawczych: marketing medialny, promocja, zachowania konsumenckie, komunikacja marketingowa, marketing polityczny. 